\title{
Uptake of preventive health care among Mediterranean migrants in Belgium
}

\author{
P Van der Stuyft, $M$ Woodward, J Amstrong, A De Muynck
}

\begin{abstract}
Study objective-The aim was to investigate the influence of ethnicity on the demand for preventive care by Mediterranean migrants in Belgium.

Design-This was a survey of patient contacts with general practitioners.

Setting and patients-33 general practitioners working in Belgian localities with the highest migrant density collaborated in the study. During two months they recorded information on consultations with an estimated 72600 clients. Participation was obtained from all subjects attending for preventive care or for a new episode of illness $(n=6256)$.
\end{abstract}

Main results-An average of $30 \%$ of the patients sought preventive care, but multivariate analysis showed ethnicity to be a strong independent predictor of this type of demand. The higher primary preventive uptake by female Moroccans and Turks and the higher secondary preventive uptake by males from the same ethnic groups, as compared with the Belgian reference population, contrasted with a lower demand for tertiary prevention in migrants of either gender. The relative demand for preventive care by the more acculturated migrants was, however, quite similar to the demand of the Belgian population.

Conclusions-The differential uptake of primary preventive care could be partly explained by the higher fertility rates of immigrant women, and the differential secondary uptake by a lower incidence of tuberculosis in the indigenous population. The meagre demand for tertiary prevention by Moroccan and Turkish migrants could be due to weaker compliance with treatments for chronic disorders, which is related to the perceptions of illness in these ethnic groups. The establishment of cross cultural mechanisms of dialogue should enhance compliance and improve the access of immigrants to the benefits of tertiary preventive care.

f Epidemiol Community Health 1993; 47: 000-000

Mediterranean migrants constitute $9 \%$ of the Belgian population but their geographical distribution is not homogeneous and they tend to concentrate in clusters. ${ }^{1}$ Family practitioners working in those neighbourhoods with high migrant density are frequently confronted with migrants' specific health problems. These were categorised by Gentilini ${ }^{2}$ as belonging to three groups: imported diseases, diseases acquired due to exposure to a new climate, a new psychocultural environment and working or housing conditions, and finally the diseases related to the integration process. The former were an important source of health problems for Mediterranean migrants in the sixties, but in the eighties they suffer from imported diseases at the same rate as the indigenous population suffers from traveller's diseases. ${ }^{34}$ At present the integration process in itself is the main cause of specific morbidity in Mediterranean migrants.

Migration has been described as having an effect on the overall health status and on the health care demand of displaced persons. While forced migration generally tends to have an impact on both, voluntary migration is nearly exclusively associated with changes in health care demand. ${ }^{5}$ As Mediterranean migrants came to Belgium voluntarily, effects on health care demand would mainly be expected. This hypothesis has been confirmed, and it has been shown that the level of acculturation in the host country influences the utilisation pattern of primary health care. ${ }^{6}$ It remains, however, unclear whether ethnicity as such is a major determinant of preventive demand or whether other socioeconomic and cultural factors play a role, as suggested in an analytical framework for the uptake of antenatal care. ${ }^{7}$ In this paper the impact of ethnicity on the preventive health care demand is examined more closely.

\section{Methods}

STUDY DESIGN

A survey of patient consultations with general practitioners was carried out in Antwerp, Ghent, and Brussels, major Belgian cities, and in eight localities of the province of Limburg. The environments in which all the studied populations live are characterised by high migrant densities ${ }^{1}$ but can be contrasted, in broad terms, as urban (the former) and rural (the latter). In the remainder of this paper they will be referred to as respectively the urban and the rural setting.

In the urban setting eight general practitioners who specialise in migrant health problems collaborated in the study, together with eight others selected from the same neighbourhood. In the rural environment, 17 doctors with an interest in migrant health care were selected. The 33 participating general practitioners had a total clientele of approximately 72600 regular patients.

The survey was conducted among clients attending in the early summer, May and June, of 1984 and 1986 respectively. Patients contacting for preventive care or for a new episode of illness 
were informed about the study objectives and permission was obtained from virtually all of them to record information for research purposes. This enabled us to enrol 6256 subjects in the study.

\section{DESCRIPTION OF DATA}

An ad hoc form and a detailed code book were developed and duly tested; factors recorded were: the nature of care provided (preventive or curative), ethnic group (possibly different from nationality held), age, gender, origin (rural or urban), situation on the labour market, and number of children in the family. The type of preventive care sought at consultation was further broken down into: primary (such as vaccinations), secondary (eg, screening procedures), and tertiary (management of long term treatments for ailments such as diabetes and hypertension).

Information on the length of stay in Belgium, knowledge of the local language, and style of dressing was obtained for migrants only. The latter two variables were rated on a three point ordinal scale (language: complete language barrier, verbal communication possible but with difficulty, verbal communication without any major problem; style of dressing: according to the traditional culture, mixture of traditional and Western elements, complete Western style). Observation on these characteristics during consultation was straightforward and the reproducibility of recording by the general practitioners was high.

In this account the patients who visited the participating general practitioners will be divided into four ethnic groups: Belgian, Moroccan, Turkish, and other Mediterranean (mainly Italian, but also including a few Greeks and Spaniards).

\section{STATISTICAL ANALYSIS}

The data from this study have been analysed to identify the factors that determine whether a consultation is for preventive or curative health care. Formally this has been achieved by both log-linear modelling and logistic regression, which are essentially equivalent techniques in this situation. ${ }^{8}$ For logistic regression the outcome variable was taken to be the proportion seeking preventive care. Analysis was carried out using the statistical computer packages GLIM and SPSS.

\section{Results}

Table I presents the major demographic characteristics and the ethnic composition of the study population. The children in the study almost always sought curative care only (more than $90 \%$ of recordings in all ethnic groups).
Table II summarises the type of care sought by patients over 14 years old. It is interesting to note that the percentages seeking preventive, curative, and both preventive and curative care were very similar across the ethnic groups. These similarities, however, mask important differences in subpopulations, as is reported subsequently.

Table III gives a breakdown of the visits for preventive care listed in table II into primary, secondary, and tertiary prevention. Women clearly made more use of primary preventive care, especially among the Moroccan and Turkish immigrants. Secondary preventive care is rather unusual, except for Moroccan and Turkish men. In broad terms the Belgian and "Other Mediterranean" groups were similar with respect to uptake of preventive care, as were the Moroccan and Turkish groups.

Since this could be related to the age structure of the different study populations, the data were divided into subsets defined by age (see table IV). As there were so few migrants aged over 64 years old, this group was excluded from further analysis. Four analyses were carried out for each of the three remaining age groups, to identify the factors which affected the propensity to seek preventive care overall, primary preventive care, secondary preventive care, and tertiary preventive care. The potential determinants considered were: study setting (urban and rural), gender, and ethnic group.

The factors which turned out to have a significant main effect were those specified in table IV. It is clear that ethnicity has a consistent effect on the propensity to seek preventive rather than curative care. Furthermore there were, in all age groups, significant interactions between study setting and ethnicity. That is, the ethnic groups acted differently in the two settings with regard to preventive overall uptake. This suggests that they need to be analysed separately.

This analysis leads to the following main findings (besides the ones already noted from table IV): in children, most preventive care was primary and there were no gender differences; in young adults, females mostly use primary preventive care and males hardly use preventive care at all; older adults mostly use tertiary care. For a more detailed look at the other determinants the data were subdivided by age (but now using only two age groups: 0-14 years old, and 15-64 years old), setting, and nationality. For each of the resulting subpopulations all potential determinants of utilisation were retained to construct a logistic regression model.

For children (below 15 years old) the only significant effect was found in Belgians from the
Table I Study population by ethnic group, study setting, age, and gender.

\begin{tabular}{|c|c|c|c|c|c|c|c|c|c|c|}
\hline \multirow{2}{*}{$\begin{array}{l}\text { Age } \\
\text { (years) }\end{array}$} & \multirow[b]{2}{*}{ Gender } & \multicolumn{2}{|l|}{ Belgian } & \multicolumn{2}{|c|}{ Moroccan } & \multicolumn{2}{|l|}{ Turkish } & \multicolumn{2}{|c|}{ Other Med } & \multirow[b]{2}{*}{ Total } \\
\hline & & Urban & Rural & Urban & Rural & Urban & Rural & Urban & Rural & \\
\hline $0-14$ & $\begin{array}{l}\text { Male } \\
\text { Female }\end{array}$ & $\begin{array}{l}149 \\
121\end{array}$ & $\begin{array}{l}214 \\
222\end{array}$ & $\begin{array}{r}100 \\
94\end{array}$ & $\begin{array}{l}27 \\
17\end{array}$ & $\begin{array}{l}86 \\
89\end{array}$ & $\begin{array}{l}45 \\
35\end{array}$ & $\begin{array}{l}33 \\
31\end{array}$ & $\begin{array}{l}60 \\
44\end{array}$ & $\begin{array}{l}714 \\
653\end{array}$ \\
\hline $15-44$ & $\begin{array}{l}\text { Male } \\
\text { Female }\end{array}$ & $\begin{array}{l}330 \\
602\end{array}$ & $\begin{array}{l}410 \\
511\end{array}$ & $\begin{array}{l}124 \\
169\end{array}$ & $\begin{array}{l}44 \\
22\end{array}$ & $\begin{array}{r}78 \\
162\end{array}$ & $\begin{array}{l}82 \\
77\end{array}$ & $\begin{array}{l}67 \\
87\end{array}$ & $\begin{array}{l}134 \\
130\end{array}$ & $\begin{array}{l}1269 \\
1760\end{array}$ \\
\hline $45-64$ & $\begin{array}{l}\text { Male } \\
\text { Female }\end{array}$ & $\begin{array}{l}245 \\
333\end{array}$ & $\begin{array}{l}184 \\
279\end{array}$ & $\begin{array}{l}41 \\
50\end{array}$ & $\begin{array}{r}38 \\
4\end{array}$ & $\begin{array}{l}14 \\
20\end{array}$ & $\begin{array}{l}32 \\
26\end{array}$ & $\begin{array}{l}25 \\
36\end{array}$ & $\begin{array}{l}61 \\
81\end{array}$ & $\begin{array}{l}640 \\
829\end{array}$ \\
\hline \multirow[t]{2}{*}{ over 64} & $\begin{array}{l}\text { Male } \\
\text { Female }\end{array}$ & $\begin{array}{l}0 \\
0\end{array}$ & $\begin{array}{l}128 \\
219\end{array}$ & $\begin{array}{l}0 \\
0\end{array}$ & $\begin{array}{l}0 \\
0\end{array}$ & $\begin{array}{l}0 \\
0\end{array}$ & $\begin{array}{l}1 \\
1\end{array}$ & $\begin{array}{l}0 \\
0\end{array}$ & $\begin{array}{l}21 \\
21\end{array}$ & $\begin{array}{l}150 \\
241\end{array}$ \\
\hline & Total & 1780 & 2167 & 578 & 152 & 449 & 299 & 279 & 552 & 6256 \\
\hline
\end{tabular}


Table II Uptake of health care in adults (over 15 years).

\begin{tabular}{lrrrr}
\hline & Type of care & & \\
\cline { 2 - 4 } Ethnicity & Preventive & Curative & \multicolumn{1}{c}{ Both } & Total \\
\hline Moroccan & $111(23 \%)$ & $366(74 \%)$ & $15(3 \%)$ & 492 \\
Turkish & $103(21 \%)$ & $370(75 \%)$ & $20(4 \%)$ & 493 \\
Other Mediterranean & $147(22 \%)$ & $496(75 \%)$ & $20(3 \%)$ & 663 \\
Belgian & $864(27 \%)$ & $2197(68 \%)$ & $180(5 \%)$ & 3241 \\
Total & $1225(25 \%)$ & $3429(70 \%)$ & $235(5 \%)$ & 4889 \\
\hline
\end{tabular}

Table III Uptake of preventive health care in adults (over 15 years)

\begin{tabular}{llccc}
\hline \multirow{2}{*}{ Ethnicity } & Gender & \multicolumn{3}{c}{ Type of preventive care } \\
\cline { 2 - 5 } Moroccan & Primary & Secondary & Tertiary \\
\cline { 2 - 5 } Turkish & female & $65(73 \%)$ & $13(35 \%)$ & $21(57 \%)$ \\
& male & $4(1 \%)$ & $23(26 \%)$ \\
female & $67(69 \%)$ & $5(19 \%)$ & $17(65 \%)$ \\
Other Mediterranean & male & $1(2 \%)$ & $4(7 \%)$ & $25(26 \%)$ \\
& female & $57(53 \%)$ & $5(5 \%)$ & $54(91 \%)$ \\
\multirow{2}{*}{ Belgian } & male & $29(9 \%)$ & $16(5 \%)$ & $277(86 \%)$ \\
& female & $296(41 \%)$ & $36(5 \%)$ & $390(54 \%)$ \\
\hline
\end{tabular}

urban study, where age was positively associated with the uptake of preventive care. The lack of any significant factors among other subgroups could merely be due to small numbers.

For adults (15-64 years old) the significant main effects that were found are listed in table V. In some cases, there were also significant interactions and the interpretation of the effect of any variable in isolation must be viewed with caution. If no interactions are found to be important, then the main effects can be meaningfully interpreted through the odds ratios. Table VI presents the odds ratios and $95 \%$ confidence intervals associated with each factor that was significant when taken alone (ie, with a significant main effect but no interaction).

For all the other variables which appear in table $\mathrm{V}$ but not in table VI, there is an interaction with at least one of the other variables, but in all instances the direction of the main effect agrees with that shown by the odds ratios above. Propensity to seek preventive care is thus always highest for females, people from rural origin, unemployed people, and those who are more traditionally dressed, and consultations are less likely to be for preventive health care for those patients who have become more adapted to the western way of life. Above all, the uptake of preventive care is strongly determined by ethnicity.

Table IV Determinants of the uptake of preventive care: significant main effects $(p \leqslant 0.05)$ from the separate analysis by age group

\begin{tabular}{|c|c|c|c|}
\hline \multirow[b]{2}{*}{ Type of preventive care } & \multicolumn{3}{|l|}{ Age group (years) } \\
\hline & Below 15 & $15-44$ & $45-64$ \\
\hline $\begin{array}{l}\text { Preventive overall } \\
\text { Primary preventive } \\
\text { Secondary preventive } \\
\text { Tertiary preventive }\end{array}$ & $\begin{array}{l}\text { ethnicity, setting } \\
\text { ethnicity, setting } \\
\text { setting }\end{array}$ & $\begin{array}{l}\text { ethnicity, setting, gender } \\
\text { ethnicity, setting, gender } \\
\text { ethnicity }\end{array}$ & $\begin{array}{l}\text { ethnicity, setting } \\
\text { ethnicity } \\
\text { ethnicity }\end{array}$ \\
\hline
\end{tabular}

Table $V$ Determinants of the uptake of preventive care in adults (15-64 years): significant main effects $(p \leqslant 0.05)$ from the separate analysis by ethnic group and study setting.

\begin{tabular}{lll}
\hline & Study setting & \\
\cline { 2 - 3 } Ethnicity & Urban & Rural \\
\hline Moroccan & stay, dress & job, origin \\
Turkish & gender, origin & gender, job \\
$\begin{array}{l}\text { Other Mediterranean } \\
\text { Belgian }\end{array}$ & $\begin{array}{l}\text { gender, job, dress } \\
\text { gender, age, job }\end{array}$ & $\begin{array}{l}\text { gender, age, job, dress } \\
\text { gender, age, job, household size }\end{array}$ \\
\hline
\end{tabular}

\section{Discussion}

Inside the ethnic groups the demand for preventive care is, quite naturally, mainly determined by age and gender. Since the composition of the studied subpopulations varied with regard to these variables, they confounded the crude results for other determinants. After control of confounding the preventive demand profile of Moroccan and Turkish patients is quite similar, with a two times higher primary and two and half times higher secondary preventive uptake than the Belgian patients, but only half the indigenous tertiary uptake.

Ethnic differences in the overall demand for preventive care have been attributed to the social position of minority groups in the dominant society, ${ }^{9}$ and a higher uptake of preventive health care has been explained on the basis of the latent social functions it performs, eg, coping with failure, status building, and pursuing integration. ${ }^{10}$ Few studies, however, have distinguished between the different types of preventive care.

In our view the higher primary preventive demand observed in this study, predominantly in migrant females, can be largely attributed to the different fertility patterns of the immigrant and indigenous populations. Persistent higher fertility rates have been documented in migrant women in general, ${ }^{11} 12$ and in Maghrebians in particular. ${ }^{13}$ At the same time there seem to be indications that Belgian women preferentially consult a gynaecologist $^{1415}$ while migrants rely more often on the general practitioner for antenatal services. ${ }^{16}$ These two phenomena might explain the relative difference observed between the ethnic groups and would bring our observations in line with Bamford, ${ }^{11}$ who documented an uptake of antenatal care for migrant Asian women which was comparable to that of British mothers.

The higher secondary preventive demand is exclusively found in Moroccan and Turkish males. It could be partly explained by the excess risk for tuberculosis (TB) among those migrants ${ }^{17}$ and by racial differences in susceptibility for tuberculosis and in tuberculosis morbidity rates, which have been widely documented. ${ }^{18}$ One might further hypothesise that bias on the part of the general practitioner leads to more thorough investigation in male migrants and eventually further contributes to the observed pattern of uptake of secondary preventive care.

The smaller tertiary preventive demand in migrants of either gender seems consistent with earlier reports of more frequent "doctor shopping", 19 higher utilization rates of alternative medicine, ${ }^{20}$ pragmatic and partial use of the Western health care system, ${ }^{21}$ and a higher dropout rate during treatment for chronic disorders. $^{22} 23$ A more comprehensive attempt at explaining this difference could use one of the frameworks proposed by Anderson. ${ }^{24}$ Within the sociocultural paradigm, the positive association between acculturation and the uptake of tertiary prevention observed in this study corroborates earlier findings: Suchman ${ }^{25}$ identified the tendency for exclusive interaction with others from the same ethnic background, the importance attached to custom and the scepticism of medical care as determinants of the use of (Western) health services. 
Table VI Odds ratios (OR) and 95\% confidence intervals (CI) for independent determinants of the uptake of preventive health care in adults (15-64 years).

\begin{tabular}{|c|c|c|}
\hline Ethnicity and study setting & $O R$ & $95 \% \mathrm{CI}$ \\
\hline $\begin{array}{l}\text { Morroccans } \\
\text { Urban setting } \\
\text { - Length of stay in Belgium }(<5 \text { years : } \geqslant 5 \text { years) } \\
\text {-Style of dress (mixed : western) } \\
\text { (traditional : western) }\end{array}$ & $\begin{array}{l}2 \cdot 0 \\
2 \cdot 0 \\
6 \cdot 2\end{array}$ & $\begin{array}{l}1 \cdot 0-3 \cdot 8 \\
1 \cdot 0-4 \cdot 4 \\
3 \cdot 2-12 \cdot 1\end{array}$ \\
\hline $\begin{array}{l}\text { Rural setting } \\
\text {-Economic activity (none : active) } \\
\text {-Origin (rural : urban) }\end{array}$ & $\begin{array}{r}6 \cdot 8 \\
10 \cdot 8\end{array}$ & $\begin{array}{l}1 \cdot 8-25 \cdot 0 \\
1 \cdot 2-93 \cdot 9\end{array}$ \\
\hline $\begin{array}{l}\text { Turkish } \\
\text { Urban setting } \\
\text { —Gender (female : male) } \\
\text { —Origin (rural : urban) }\end{array}$ & $\begin{array}{l}2 \cdot 4 \\
1 \cdot 1\end{array}$ & $\begin{array}{l}1 \cdot 3-4 \cdot 7 \\
1 \cdot 0-1 \cdot 5\end{array}$ \\
\hline $\begin{array}{l}\text { Rural setting } \\
\text {-Gender (female : male) } \\
\text {-Economic activity (none : active) }\end{array}$ & $\begin{array}{l}3 \cdot 2 \\
2 \cdot 5\end{array}$ & $\begin{array}{l}1 \cdot 2-8 \cdot 5 \\
1.0-6 \cdot 7\end{array}$ \\
\hline $\begin{array}{l}\text { Other Mediterranean } \\
\text { Urban setting } \\
\text {-Style of dress (mixed traditional }{ }^{a}: \text { western) }\end{array}$ & $2 \cdot 0$ & $1 \cdot 0-4 \cdot 4$ \\
\hline
\end{tabular}

The social-psychological approach further addresses how persons decide on a particular source of care. In Mechanic's view ${ }^{26}$ the final decision depends on one's knowledge about the medical conditions underlying symptoms, one's competing needs, and the availability of treatment. The specific relation between patient's beliefs and perceptions of illness, mediated by ethnic origin, and compliance with treatments for chronic disorders such as hypertension and diabetes, has been documented in more recent studies. $^{2728}$ Lesser compliance among migrants that in the indigenous population might thus explain the observed difference in the demand for tertiary preventive care.

In summary, this study refines earlier observations 5625 which indicated that the health care behaviour of migrants tends to become comparable to that of the indigenous population when migrants become more acculturated in the host society. The detection of the significantly smaller relative demand for tertiary preventive care by Mediterranean migrants compared with Belgians is, however, the single most important finding. This type of care increases socioeconomic wellbeing and improves the quality of life through the prevention of further morbidity, complications, and even early death. Integrated primary health care and the establishment of a mechanism of dialogue between the general practitioners and the immigrant community would enhance mutual insight in the models adopted to explain chronic diseases $^{21}$ and increase the trust of the migrant patients in the local health care system. ${ }^{22}$ This could in turn contribute to enhancing the migrants' compliance and regularity, ${ }^{27}$ and improve their access to the benefits of tertiary preventive care.

The authors would like to thank the many people who have contributed to this work, especially the general practitioners who recorded information and the patients under their care. This work was supported in part by grants from the Flemish Government (G2/BB/7019), the National Belgian Government (BTK 30244), the EEC (Eramus SVS-87-B0039), the NFWO (CD/E 193/1988), and the British Counsel (BEL/0601/642).

1 Van de Mieroop E, Peeters R, De Muynck A. Atlas van ethnische minderheden in Vlaanderen en Brussel. Antwerpen: UIA-IMT, 1989.

2 Gentilini M. Aspects épidémiologiques des migrants en France. Bull INSERM 1971; 26: 431-522.

3 De Muynck A, Schillemans L. Incidence de la pathologie d'importation vue par le médecin de famille belge. Méd Maladies Infect 1986; 5: 396-8.

4 Gentilini M, Brücker G. La migration: flux et reflux. Pathologie des Migrants 1984; 34: 3197-207.

5 McKinlay JB. Some issues associated with migration, health status and the use of health services. $f$ Chron Dis $1975 ; 28$ : 579-92.

6 Van der Stuyft P, De Muynck A, Schillemans L, Timmerman C. Migrants, acculturation and utilization of primary health care. Soc Sci Med 1989; 29: 53-60.

7 Da Silveira VC, De Muynck A, Timmerman C, Van der Stuyft $P$. Development and uses of a conceptual model in the study of antenatal services utilization by migrant women in Belgium. Health and Community: ITG working paper No 19,1988

8 Woodward M, Francis L. Statistics for health management and research. London: Edward Arnold, 1988.

9 Roberts RE, Sul Lee E. Medical care use by MexicanAmericans. Med Care 1980; 28: 266-81.

0 Shuval J. Social functions of medical practice. San Francisco: Jossey-Bass, 1970.

11 Bamford N. Immigrant mother and her child. BMF 1971; i: 276-80.

12 Hopkins $\mathrm{D}$, Clarke $\mathrm{N}$. Indochinese refugee fertility rates and pregnancy risk factors, Oregon. Am $\mathcal{f}$ Public Health 1983; 73: $1307-9$.

13 Wijewickrema S. Fertility adaption to local conditions: Maghrebians in Belgium. Interuniversitary Programme in Demography-Working Paper 1989-3. Brussels: VUB, 1983.

14 Wollast E, Vandenbussche P, Buekens P. Evaluation de la surveillance prénatale en Belgique et comparaison entre les secteurs publics et privés. Rev Epidémiol Santé Publique 1986; 34: 52-8.

15 Foets M, Berghmans F, Janssens $L$. The primary health care project in Belgium: a survey on the utilization of health services. Soc Sci Med 1985; 20: 181-90.

16 De Muynck A, Lammers M, Timmerman C, Eggermont R. Prenatale consultatie door migrantenvrouwen in Vlaanderen: Een Dilemma? Antwerpen: ITG, EPI Publicatie No 7 1989.

17 Schillemans L, De Muynck A. Problematiek van de eerstelijns-zorgenverstrekking aan Marokkanen en Belgen te Borgerhout. Tijdschrift voor Geneeskunde 1984; 40: te Borger 47 .

18 Kushigemachi M, Schneiderman LJ, Barrett-Connor E. Racial differences in susceptibility to tuberculosis: risk of Racial differences in susceptibility to tuberculosis: risk
disease after infection. $₹$ Chron Dis $1984 ; 37: 853-62$.

19 Schillemans L, De Muynck A, Lammers M, Timmerman C. Hulpverlenen door de huisarts aan (Marokkaanse) Hulpverlenen door de huisarts aan (Marokkan

20 De Muynck A, De Clerck J, Baeten R, Lammers M, Van der De Muynck A, De Clerck J, Baeten R, Lammers M, Van der
Stuyft P. Medische zorgenvraag van allochtonen en Belgen bij de Limburgse huisarts. Hasselt: ITG en Provinciale Dienst voor Onthaal van Gastarbeiders, 1988

21 Peeters RF. Health and illness of Moroccan immigrants in the city of Antwerp, Belgium. Soc Sci Med 1986; 22: $679-85$.

22 Schillemans L, De Muynck A, Saenen R, Van der Stuyft P, Maes R. Hulpverlenen aan migranten: goede bedoeling volstaan niet. Huisarts $\mathrm{Nu} 1989 ; 18$ : 521-5.

23 Schillemans L, De Muynck A, Van der Stuyft P, Saenen R, Baeten R. Assessment of patients' health status in family medicine Quality Assurance in Health Care 1990; 2 . $161-70$.

24 Anderson J. Health Services utilization: framework and review. Health Serv Res 1973; 8: 184-99.

25 Suchman EA. Social patterns of illness and medical care. $f$ Health Hum Behav 1965; 6: 2-16.

26 Mechanic D. Medical sociology: a selective view. New York: Free Press, 1968.

27 Heurtin-Roberts S. Health beliefs and compliance with prescribed medication for hypertension among black
women-New Orleans, 1985-86. fAM $1990 ; 264: 2864$.

28 Dechamp-Le-Roux C, Valensi P, Assad N, Sislian P, Attali JR. Beliefs in diabetics about the etiology of their disease. Influence of ethnicity. Diabete Metab 1990; 16: 207-12. 